\title{
Study of Antimicrobial, Antioxidant and Cytotoxicity Properties of Selected Plant Extracts for Food Preservative Applications
}

\author{
Tania Islam ${ }^{\mathrm{a}}$, Md NazRul Islam ${ }^{\mathrm{a}}$, Wahidu Zzaman ${ }^{\mathrm{b}}$, And Md Morsaline Billah $^{\mathrm{c}}$ \\ ${ }^{a}$ Forestry and Wood Technology Discipline, Khulna University, Khulna - 9208, Bangladesh \\ b Department of Food Engineering and Tea Technology, Shahjalal University of Science and Technology, Sylhet \\ 3114, Bangladesh \\ ${ }^{\mathrm{c}}$ Biotechnology and Genetic Engineering Discipline, Khulna University, Khulna - 9208, Bangladesh \\ ${ }^{*}$ Corresponding author \\ nazrul17@yahoo.com \\ TEL.: 88041 730171-3, ExT: 2070
}

Received: 24 August 2019; Published online: 24 February 2021

\begin{abstract}
An attempt has been made to evaluate antimicrobial, antioxidant and cytotoxicity properties of extracts from onion (Allium cepa L.), garlic (Allium sativum), leaves of guava (Psidium guajava), papaya (Carica papaya), tea (Camellia sinensis), baen (Avicennia alba) and keora (Sonneratia apetala), respectively to apply as natural preservatives for tomatoes. The air-dried plant materials of the respective plant species were subjected to ethanol-methanol extraction, concentrated and stored at $4^{\circ} \mathrm{C}$ before use. The extracts were dissolved in $95 \%$ ethanol for analysis of antioxidant and antimicrobial properties. Of the extracts tested, tea extracts showed the highest zone of inhibition against several pathogenic bacteria (E. coli $35.0 \pm 3.2 \mathrm{~mm}$; P. aeruginosa $29.3 \pm 2.6 \mathrm{~mm}$; S. typhi $28.4 \pm 2.1 \mathrm{~mm}$ and S. pyogenes $27.7 \pm 3.7 \mathrm{~mm}$ ) using the disc diffusion method. In regard to DPPH free radical scavenging assay, keora and guava extracts showed the highest percentage of radical scavenging activity with the values of $89.64 \pm 0.18$ and $89.39 \pm 0.88$, respectively, which were in agreement with higher total antioxidant capacity (TAC) of these extracts obtained by the phosphomolybdenum method. Brine shrimp lethality bioassay for cytotoxicity assessment showed $\mathrm{LC}_{50}$ of $132.54 \pm 18.99 \mu \mathrm{g} / \mathrm{mL}$ for the leaf extract of keora which was found to be most toxic among all studied extracts. The initial results indicated that the extracts could be used for food preservative applications based on the antimicrobial, antioxidant and cytotoxicity properties of the tested extracts. However, efficacy, stability and safety issues need to be addressed with both in vitro and in vivo studies.
\end{abstract}

Keywords: Antimicrobial; Antioxidant; Cytotoxicity; Nutrient content; Natural food preservative

\section{Introduction}

Plants have been used for treating ailments and different diseases since prehistoric times. Remnants from different civilizations still carry the evidence of plant usage for different purposes (Hintz, Matthews \& Di, 2015). Mankind is utilising plant extracts and oils for thousands of years for many purposes including food preservation and therapeutics (Hammer, Carson \& Riley, 1999). Plant-based foods are prone to deteriorate at some rate after harvesting due to physical interventions, and chemical and microbial reactions (Nakanishi, Irie \& Murata, 2018; Thielmann, Kohnen \& Hauser, 2017), which lead to loss of quality and shelf life reduction. Different 


\section{Nomenclature}

\author{
FDA Food and Drug Administration \\ AAE Ascorbic Acid Equivalent \\ GAE Gallic Acid Equivalent \\ DMSO Dimethyl Sulfoxide
}

\author{
BSA Bovine Serum Albumin \\ LC Lethal Concentration \\ DPPH 2,2-diphenyl-1-picrylhydrazyl \\ ZOI Zone of Inhibition
}

types of methods such as freezing, smoking, heating, sun drying, irradiation and chemical treatments are in place alone or in combination for preservation of foods. A global estimate for food loss has revealed that $10 \%$ of cereal and $40 \%$ of vegetables and fruits, including $75 \%$ of peas and beans are lost during storage every year. The estimate goes up if meat, poultry and fish are considered (Kumar \& Kalita, 2017). Therefore, loss during postharvest storage raises the price of food, affecting its availability and access, if proper control measures are not undertaken (Hac-Wydro, Flasinski \& Romanczuk, 2017). In addition, it also increases the potential for food contamination by food borne pathogens and insects. As a result, contaminated food leads to an increased risk of human illnesses along with a reduction in the nutritional quality of the food (Sarkar \& Shetty, 2014).

There are increasing consumer demands for less use of synthetic additives in processed food products. Although synthetic antimicrobials are approved in many countries, the recent trend towards use of natural preservatives is due to the adverse health effect of synthetic ones (Khan, Ullah \& Oh, 2016; King et al., 2017). Due to inherent chemical diversity and the unique classes of compounds produced by plants as self-defence mechanisms against infectious organisms, plant based natural products, either as pure compounds or standardized extracts, offer unlimited opportunities for control of microbial growth. In addition, the use of plant extracts in food applications has increased as several are generally recognized as safe (GRAS) by the Food and Drug Administration (FDA). A variety of different compounds in plant extracts possess antimicrobial activities, and several extracts have been shown to have antimicrobial activity due to their phytochemical constituents (Ma et al., 2018; Shiekh, Malik, Al-Thabaiti \& Shiekh, 2013). The antibacterial activity could be attributed to the combined effects of adsorption by bacterial membranes of polyphenols, with membrane disruption leading to leakage of cellular contents and the formation of hydroperoxides from polyphenols. Plant extracts also exhibit antifungal, antioxidant and antimutagenic activities, and inhibit lipid oxidation in foods. Numerous in-vitro studies have been carried out to evaluate the antimicrobial activity of plant extracts (Donsi \& Ferrari, 2016). However, very little information is available for food products. Most of the studies employed crude extracts and resulted in reduced inhibition when compared with many of the pure compounds in foods. Dietary herbs and spices have traditional applications as food additives to improve the sensory characteristics of foods and extend their shelf life by reducing or eliminating survival of pathogenic bacteria. These herbs and spice extracts usually possess antimicrobial activity against different bacteria, yeast and moulds as they are rich in phenolic compounds (Dwivedy, Kumar, Upadhyay, Prakash \& Dubey, 2016).

Apart from antimicrobial properties, the extracts are shown to preserve foods by reducing lipid oxidation due to their significant antioxidant activity. Various phenolic substances derived from herbs and spices are reported to show several biological activities which contribute to their preservative potential (Negi, 2012; Sumaiya, Jahurul \& 
Zzaman, 2018). It has also been found that antioxidants may protect cell tissues from free radicals and thus have a role in the prevention of diseases like cancer (Djeridane et al., 2006). With evolving health consciousness and increasing concerns regarding the use of synthetic antioxidants to prevent oxidation reactions in food, the use of safe plant-based antioxidants and antimicrobials has drawn considerable interest and attention of scientists and industrialists. This has resulted in the use of plant based bioactive compounds in food preservation (Thorat et al., 2013). Agricultural and horticultural produce, especially plants and fruits which are rich in phenolic bioactive compounds, provide a mixture of phytochemicals with potential health benefits. These bioactive phenolic compounds also can improve storage quality and increase the shelf life of other fruits, vegetables, legumes, grains and other food products (Thielmann et al., 2017). The present study was undertaken to determine and compare the potential of extracts of onion (Allium cepa L.), garlic (Allium sativum), leaves of guava (Psidium guajava), papaya (Carica papaya), tea (Camellia sinensis), baen (Avicennia alba) and keora (Sonneratia apetala), respectively as natural preservatives for tomatoes.

\section{Materials and Methods}

\section{$2.1 \quad$ Materials}

The samples of onion and garlic were collected from the Gallamari Market near Khulna University campus at Khulna, Bangladesh. The leaves of guava ( $P$. guajava) and papaya (C. papaya) were collected directly from the mature trees located on the Khulna University campus. The mature tea $(C$. sinesis) leaves were collected from a tea garden located in Sylhet, Bangladesh. The leaves of baen $(A$. alba) and keora ( $S$. apetala) were collected from Dhangmaree, Chadpai range, East zone of the Sundarbans, Bangladesh. The leaves of guava ( $P$. guajava), papaya (C. papaya), tea $(C$. sinesis), baen $(A$. alba) and keora $(S$. apetala) were washed thoroughly using distilled water to remove dirt and other unwanted pollutants and then kept at room temperature for surface drying. The outer layer of onion and gar- lic were peeled carefully, and the inner portion was kept for further use. The samples were then cut into small pieces, air dried for $24 \mathrm{~h}$ and subsequently dried in the oven for $24 \mathrm{~h}$ at $80{ }^{\circ} \mathrm{C}$. Dried samples were ground later into a coarse powder (40-mesh) and placed in separate airtight glass bottles. Powdered samples were stored in a refrigerator at $4{ }^{\circ} \mathrm{C}$ until they were removed for further processing.

\section{$2.2 \quad$ Extraction of plant extracts}

Approximately $500 \mathrm{~g}$ of dried powdered sample was placed in a $5 \mathrm{~L}$ round bottom flask and soaked in $2.5 \mathrm{~L}$ of an ethanol (>99.5\%)-methanol $(>95 \%)$ mixture $(50 \% \mathrm{v} / \mathrm{v}$ basis $)$. The flask containing the mixture was kept airtight, using a cotton plug and aluminium foil, and magnetically stirred at $500 \mathrm{rpm}$ at room temperature for 20 h. The extract was filtered through a fresh cotton plug, followed by Whatman No.1 filter paper, and concentrated using a rotary evaporator $(\mathrm{Bu}-$ chi Labortechnik AG, Flawil, Switzerland). The resultant extracts were stored in a refrigerator until required for the experiments. The weight of the crude extract obtained from leaves was found to be in the range of 5-10 g as oven dried.

\subsection{Antimicrobial activity assessment}

Antibacterial activity of the extracts was evaluated by the disc diffusion method (Bauer, Kirby, Sherris \& Turck, 1966). Escherichia coli (ATCC 8739), Pseudomonas aeruginosa (ATCC 27833), Salmonella typhi (ATCC 6539) and Streptococcus pyogens (ATCC 19615) were collected as pure cultures from the Microbiology Laboratory, Pharmacy Discipline, Khulna University, Bangladesh. The bacterial isolates were cultured in nutrient broth at $37^{\circ} \mathrm{C}$ for $2-4 \mathrm{~h}$ until the $\log$ phase of growth. The sterile filter paper discs were prepared by adding the desired concentration $(250 \mu \mathrm{g} /$ disc $)$ of extract onto the disc using a micropipette. Bacterial broth culture was spread over the nutrient agar medium. Finally, the plates were incubated at $37{ }^{\circ} \mathrm{C}$ for $18 \mathrm{~h}$ and then checked for the zone of inhibition, which was measured in millimetres ( $\mathrm{mm})$. Erythromy- 
cin $(10 \mu \mathrm{g} /$ disc $)$ was used as a control during the study.

\section{Antioxidant activity assessment}

The free radical scavenging properties of extracts were evaluated by the 2,2-diphenyl-1picrylhydrazyl (DPPH) assay method as modified by Brand-williams, Cuvelier and Berset (1995). Then, $2 \mathrm{~mL}$ of different concentrations $(1.75,3.13,6.25,12.5,25,50,100,200$ and 400 $\mu \mathrm{g} / \mathrm{mL}$ ) of the extracts were mixed with $3 \mathrm{~mL}$ of $0.004 \%$ DPPH solution in ethanol. After a reaction period of $30 \mathrm{~min}$ at room temperature in the dark, the absorbance was measured at 517 nm (Gupta et al., 2003). Ascorbic acid was used as the standard. Each assay was carried out in triplicate. The total antioxidant capacity of the extracts was evaluated by the phosphomolybdenum method (Prieto, Pineda \& Aguilar, 1999). Sulfuric acid, sodium phosphate and ammonium molybdate were supplied by Merck (Darmstadt, Germany). A $0.3 \mathrm{~mL}$ of extract was combined with $3 \mathrm{~mL}$ of reagent solution $(0.6 \mathrm{M}$ sulfuric acid, $28 \mathrm{mM}$ sodium phosphate and $4 \mathrm{mM}$ ammonium molybdate). The tubes containing the reaction solution were incubated at $95{ }^{\circ} \mathrm{C}$ for $90 \mathrm{~min}$. Then, the absorbance of the solution was measured at $695 \mathrm{~nm}$ using a UV-vis spectrophotometer (UV mini-1240, Shimadzu Corporation, Japan), against a blank, after it was cooled down to room temperature. Methanol $(0.3 \mathrm{~mL})$ in the place of extract was used as the blank. The total antioxidant activity was expressed as ascorbic (AAE) and gallic (GAE) acid equivalents, and also as the percentage of radical scavenging activity (Skrovankova, Sumczynski, Mlcek, Jurikova \& Sochor, 2015) The percentage of radial scavenging activity was calculated using the below mentioned formula:

$$
I(\%)=100 \times \frac{A_{\text {Blank }}-A_{\text {Sample }}}{A_{\text {Blank }}}
$$

where $I(\%)$ is the inhibition percentage, $A_{\text {blank }}$ is the absorbance of the control element and $A_{\text {sample }}$ is the absorbance of the test sample (Salawu et al., 2017).

\section{Cytotoxicity assessment}

The brine shrimp lethality bioassay was carried out for the cytotoxicity test and vincristine sulphate $(0.52 \mu \mathrm{g} / \mathrm{mL})$ was used as a positive control. The eggs of the brine shrimp, Artemia salina, and sea water were collected from the BRAC prawn hatchery, Sreeghat, Bagerhat, Bangladesh. $48 \mathrm{~h}$ after hatching, eggs become mature and are called nauplii. The water insoluble extracts were dissolved in $50 \mu \mathrm{L}$ of dimethyl sulfoxide (DMSO) and each test tube contained $4 \mathrm{~mL}$ of sea water with different concentrations of extracts $(5,10,20,40,80,160,320 \mu \mathrm{g} / \mathrm{mL})$. The final volume for each test tube was adjusted to $10 \mathrm{~mL}$ with artificial sea water and 10 living nauplii were transferred into each tube. After $24 \mathrm{~h}$ of incubation at room temperature $\left(25^{\circ} \mathrm{C}\right)$, the number of live and dead nauplii were recorded. The lethal concentration $\left(\mathrm{LC}_{50}\right)$ values of the plant extracts were obtained at $95 \%$ confidence interval and the slope calculated using prohibit analysis by the Finney-1971 computer program (Mwangi, Wagacha, Nguta \& Mbaria, 2015).

\section{Nutrient analysis}

The different extracts having the concentration of $0.5 \%$ were sprayed uniformly and separately on the collected tomatoes of uniform size, shape and ripening condition with the help of a hand sprayer. The fruits were then dried at room temperature and stored in an open and safe place which was free from insects. The storage duration was 12 days as reported by Islam et al. (2018). The moisture content of fruits was determined by the oven drying method (AOAC, 2005) before application of the extract and after the storage time. Weight, as an indicator of the quality of fruits, was measured using a digital balance (Brishti, Misir \& Sarker, 2013) before application of the extract and after the storage time. The tomato juice was prepared by a digital blender (Vita-Prep 3, Vita-Mix Corporation, UK) as reported by Islam et al. (2018), and the $\mathrm{pH}$ of juice was measured by a benchtop $\mathrm{pH}$ meter. Total carbohydrate content of the tomato before application of the extract and after the storage time was determined by the Lane-Eynon 
method (Okoye \& Ugwu, 2008). The protein content of tomato was estimated by Lowry's method using a standard curve of Bovine Serum Albumin (BSA) solution (20-100 mg/mL) and a double beam UV-Visible spectrophotometer to measure absorbance at a wavelength of $660 \mathrm{~nm}$ (Lowry, Rosebrough, Farr \& Randall, 1951).

\subsection{Assessment of antimicrobial and antioxidant properties of preserved tomato juice}

To evaluate the efficacy of preserved tomatoes in regard to antimicrobial and antioxidant properties, tomato juice was prepared from different tomatoes which had been coated with an extract as described earlier. In addition, fresh tomato juice was prepared to compare the effects of extract application. Antimicrobial activity assessment, free radical scavenging assay and total antioxidant capacity were conducted as stated earlier.

\section{Results and Discussion}

\subsection{Antimicrobial activities of the extracts}

Among seven different plant extracts, the leaf extract of tea showed the strongest inhibition against E. coli $(35.0 \pm 3.2 \mathrm{~mm}), P$. aeruginosa $(29.3 \pm 2.6 \mathrm{~mm})$, S. typhi $(28.4 \pm 2.1 \mathrm{~mm})$ and $S$. pyogenes $(27.7 \pm 3.7 \mathrm{~mm})$ (Table 1$)$. Garlic $(A$. sativum) extract and the leaf extract of Baen (A. alba) produced approximately similar zones of inhibition followed by the leaf extract of tea. The assay results were interpreted using the scale of measurement described by Carovic-Stanko et al. (2010) which considered zones of inhibition greater than $15 \mathrm{~mm}$ as strongly inhibitory, 10-15 $\mathrm{mm}$ as moderately inhibitory and smaller than $10 \mathrm{~mm}$ as not inhibitory, respectively. Based on this scale, the extracts used in this study showed strong inhibition at $250 \mu \mathrm{g} /$ Disc against the bacteria under investigation. However, the onion ( $A$. cepa) extract showed the lowest zone of inhibition. The strong inhibitory activity of the extracts could be attributed to the presence of a variety of flavonoids in tea (C. sinensis) (more than $30 \%$ of dry weight) as reported earlier (Reto, Figueira, Filipe \& Almeida, 2007). In the present investigation, other plant extracts also showed strong activity against the tested bacteria irrespective of their types (Dorman \& Deans, 2000). However, the extracts also showed varying levels of inhibitory properties, which could be regarded as one of key findings in this study and allowed us to investigate their properties for fruit preservation. With regard to potential antimicrobial activity, the plant extracts could be ranked as tea $(C$. sinensis $)>$ garlic $(A$. sativum $)>$ baen $(A$. alba $)>\operatorname{keora}(S$. apetala $)>$ papaya $(C$. papaya $)>$ guava $(P$. guajava $)>$ onion (A. сера).

It is worth mentioning that several previous studies showed the efficacy of plant extracts as antimicrobial agents for preventing the growth of food borne and spoilage bacteria (Calo, Crandall, O’Bryan \& Ricke, 2015; Cleveland, Montville, Nes \& Chikindas, 2001). It is well documented that plant extracts possess a number of antimicrobial compounds, e.g. terpenoid, alkaloid and phenolic compounds. These compounds usually interact with enzymes and proteins of the microbial cell membrane and subsequently lead to its disruption. These events in turn induce cell death or inhibit enzymes essential for amino-acid biosynthesis (Burt, 2004; Gill \& Holley, 2006). In addition, several researchers have reported that the inhibitory effect of these plant extracts could be correlated with their hydrophobic nature as well as the cell membrane of targeted bacteria (Gill \& Holley, 2006; Tiwari et al., 2009). This attribute would facilitate interaction of the plant extracts with microbial cell membrane protein and mitochondria, deform their structures and ultimately alter their permeability (Friedman, Henika, Levin \& Mandrell, 2004; Tiwari et al., 2009). The present study suggested that the selected plant extracts, which proved to be potentially effective, could be used as natural preservatives and alternatives to chemical preservatives which have become an increasing concern due to potential health hazards. 
SI100 | Islam et al.

Table 1: Mean values of diameters for zone of inhibition (ZOI) of different plant extracts (expressed in $\mathrm{mm}$, presented as mean \pm standard deviation; $\mathrm{n}=3$ ) and standard, Erythromycin

\begin{tabular}{|c|c|c|c|}
\hline Bacteria & Type of extracts & $\begin{array}{l}\text { ZOI diameter } \\
(\mathrm{mm})\end{array}$ & $\begin{array}{l}\text { Erythromycin } \\
(\mathrm{mm})\end{array}$ \\
\hline E. coli & $\begin{array}{c}\text { Keora } \\
\text { Tea } \\
\text { Baen } \\
\text { Papaya } \\
\text { Guava } \\
\text { Garlic } \\
\text { Onion }\end{array}$ & $\begin{array}{l}25.0 \pm 1.2^{a} \\
35.0 \pm 3.2^{b} \\
27.0 \pm 2.3^{a} \\
21.0 \pm 1.9^{c} \\
20.0 \pm 2.3^{d} \\
27.0 \pm 1.7^{a} \\
20.0 \pm 2.6^{e}\end{array}$ & $29.5 \pm 1.29^{a}$ \\
\hline P. aeruginosa & $\begin{array}{c}\text { Keora } \\
\text { Tea } \\
\text { Baen } \\
\text { Papaya } \\
\text { Guava } \\
\text { Garlic } \\
\text { Onion }\end{array}$ & $\begin{array}{l}19.5 \pm 2.3^{b} \\
29.3 \pm 2.6^{a} \\
21.4 \pm 3.1^{c} \\
19.2 \pm 2.8^{d} \\
18.7 \pm 1.7^{e} \\
25.0 \pm 1.2^{a} \\
18.3 \pm 2.8^{f}\end{array}$ & $27.75 \pm 0.96^{a}$ \\
\hline S. typhi & $\begin{array}{c}\text { Keora } \\
\text { Tea } \\
\text { Baen } \\
\text { Papaya } \\
\text { Guava } \\
\text { Garlic } \\
\text { Onion }\end{array}$ & $\begin{array}{l}20.5 \pm 2.9^{b} \\
28.4 \pm 2.1^{a} \\
22.9 \pm 2.5^{c} \\
23.5 \pm 2.7^{a} \\
19.4 \pm 2.0^{d} \\
24.5 \pm 1.8^{a} \\
19.2 \pm 2.7^{e}\end{array}$ & $28.75 \pm 0.5^{a}$ \\
\hline S. pyogenes & $\begin{array}{c}\text { Keora } \\
\text { Tea } \\
\text { Baen } \\
\text { Papaya } \\
\text { Guava } \\
\text { Garlic } \\
\text { Onion }\end{array}$ & $\begin{array}{l}24.6 \pm 3.5^{b} \\
27.7 \pm 3.7^{a} \\
25.5 \pm 3.9^{c} \\
24.5 \pm 2.9^{d} \\
23.3 \pm 3.1^{e} \\
26.3 \pm 2.7^{f} \\
23.6 \pm 2.1^{g}\end{array}$ & $32.75 \pm 0.98^{a}$ \\
\hline
\end{tabular}

Dissimilar small letters in a row indicate significant differences $(\mathrm{p}<0.005)$ of the antimicrobial effect of different extracts, respectively when compared to standard, while similar small letters in a row indicate the lack of significant differences $(\mathrm{p}<0.05)$ of the same. 
Plant extracts for food preservative applications $\mid$ SI101

Table 2: Nutrient analyses of fresh tomatoes at day 0, tomatoes without any extract coating at day 12 and tomatoes coated with different extracts at day 12 .

\begin{tabular}{cccccc}
\hline $\begin{array}{c}\text { Type of } \\
\text { extracts }\end{array}$ & $\begin{array}{c}\text { Moisture } \\
\text { content (\%) }\end{array}$ & $\begin{array}{c}\text { Changes in } \\
\text { weight (\%) }\end{array}$ & $\begin{array}{c}\mathrm{pH} \text { of the } \\
\text { fruit juice }\end{array}$ & $\begin{array}{c}\text { Total } \\
\text { carbohydrate (\%) }\end{array}$ & $\begin{array}{c}\text { Protein } \\
\text { content }(\%)\end{array}$ \\
\hline $\begin{array}{c}\text { Fresh Tomato at Day 0 } \\
\text { Tomato at day 12 }\end{array}$ & $89.93 \pm 0.15^{a}$ & - & $4.08 \pm 0.02^{a}$ & $2.42 \pm 0.03^{a}$ & $0.82 \pm 0.02^{a *}$ \\
Keora extract coated tomato & $45.85 \pm 0.27^{b}$ & $45.52 \pm 1.56^{a}$ & $6.59 \pm 0.89^{b *}$ & $0.87 \pm 0.15 \mathrm{~b}^{*}$ & $0.46 \pm 0.17^{a *}$ \\
Tea & $79.86 \pm 0.38^{c}$ & $11.24 \pm 0.24^{b}$ & $4.16 \pm 0.06^{a}$ & $2.04 \pm 0.06^{a}$ & $0.73 \pm 0.02^{a *}$ \\
Baen & $15.89 \pm 0.18^{c}$ & $5.34 \pm 0.16^{c}$ & $1.42 \pm 0.04^{c *}$ & $0.62 \pm 0.03^{a *}$ \\
Papaya & $87.64 \pm 0.58^{d}$ & $17.92 \pm 0.12^{d}$ & $5.48 \pm 0.13^{d}$ & $1.32 \pm 0.02^{d *}$ & $0.57 \pm 0.03^{a *}$ \\
Guava & $72.15 \pm 0.55^{f}$ & $19.12 \pm 0.12^{e}$ & $5.25 \pm 0.11^{e}$ & $1.72 \pm 0.05^{a}$ & $0.52 \pm 0.02^{a *}$ \\
Garlic & $69.18 \pm 0.63^{g}$ & $20.02 \pm 0.27^{f}$ & $5.40 \pm 0.10^{f}$ & $1.59 \pm 0.03^{g *}$ & $0.54 \pm 0.02^{a *}$ \\
Onion & $67.47 \pm 0.19^{h}$ & $20.28 \pm 0.07^{h}$ & $6.56 \pm 0.06^{\text {* }}$ & $0.94 \pm 0.05^{f *}$ & $0.49 \pm 0.01^{a *}$ \\
\hline
\end{tabular}

Means with the same letter in a column are not significantly different $(\mathrm{p}<0.005)$ when compared to fresh tomato at day 0, while $*$ indicates the values which are not significantly different when compared to tomatoes kept for 12 days without any extract application. Significant values $(\mathrm{p}<0.005)$ for tomatoes kept 12 days with different extract applications are shown without any symbol.

\subsection{Antioxidant properties of the extracts}

In the DPPH free radical scavenging assay, the leaf extract of keora (S. apetala) and guava $(P$. guajava) showed the highest percentage of free radical scavenging activity $(89.64 \pm 0.17$ and $89.39 \pm 0.88$, respectively) (Fig. 1). With regard to free radical scavenging activity the plant extracts were ranked as keora $(S$. apetala $)>$ guava $(P$. guajava $)>$ tea $(C$. sinensis $)>$ papaya $(C$. papaya $)>$ onion $(A$. cepa $)>$ baen (A. alba) . The ability of antioxidants to donate hydrogen is a guide to DPPH free radical scavenging. In the DPPH assay, the violet color of DPPH solution is reduced to a yellow colored product, diphenylpicryl hydrazine, with the introduction of the extracts in concentration-dependent manner. The ethanolic plant extracts showed a similar type of free radical scavenging activity when compared with the standard, ascorbic acid. It has been reported that polyphenol compounds and tocopherols scavenge the DPPH radicals by their hydrogen donating ability (Amarowicz, Pegg, Rahimi-Moghaddam, Barl \& Weil, 2004). In addition, total polyphenols content and radical scavenging antioxidant activity are found to be highly correlated. The results obtained in this study suggest that the extracts show radical scavenging activity due to their redox properties, i.e. through their electron transfer or hydrogen donating ability (Lee, Hwang, Ha, Jeong \& Kim, 2003; Rahman, Islam, Biswas \& Alam, 2015).

In terms of total antioxidant capacity, the leaf extract of guava showed the highest antioxidant capacity which was $257.10 \pm 14.97 \mathrm{mg} \mathrm{AAE} / \mathrm{g}$ and $311.19 \pm 20.22 \mathrm{mg} \mathrm{GAE} / \mathrm{g}$, respectively followed by the leaf extract of keora (S. apetala) which showed values of $135.17 \pm 0.78 \mathrm{mg} \mathrm{AAE} / \mathrm{g}$ and $163.61 \pm 0.94 \mathrm{mg}$ GAE/g, respectively (Fig. 2 ). The antioxidant potential of the different extracts was determined by their ability to reduce the reduction of Mo (VI) to Mo (V) and subsequent formation of a green phosphate/Mo (V) complex at acidic $\mathrm{pH}$. The presence of bioactive compounds, such as polyphenols, carotenoids, and vitamin $\mathrm{E}$ and $\mathrm{C}$ in the extracts influences their antioxidant activity (Mwangi et al., 2015). The presence of bioactive compounds and their concentration in the extracts is important for conferment of antioxidant activity. Thus, higher concentrations of extract show higher antioxidant activity. These results comply with previous findings, which suggested that the antioxidant capacity could be attributed to the chemical composition and polyphenol content of the extract and not just the total phenolic content (Amarowicz et al., 2004; Rahman et al., 2015; 
Table 3: Mean values of diameters for zone of inhibition (ZOI) of fresh tomato juice (TJ) at Day 0, tomato juice at Day 12 and different juices prepared from extract coated tomatoes at Day 12 (expressed in $\mathrm{mm}$, presented as mean \pm standard deviation; $\mathrm{n}=3$ ) and standard, Erythromycin

\begin{tabular}{|c|c|c|c|}
\hline Bacteria & Types of extracts & $\begin{array}{c}\text { ZOI diameter } \\
(\text { Mean } \pm \mathrm{SD}, \mathrm{mm})\end{array}$ & $\begin{array}{c}\text { Erythromycin } \\
(\text { Mean } \pm \mathrm{SD}, \mathrm{mm})\end{array}$ \\
\hline \multirow{9}{*}{ E. coli } & Fresh TJ & $24.5 \pm 0.5^{b}$ & \multirow{9}{*}{$32.5 \pm 1.34^{a}$} \\
\hline & TJ without extract & $13.3 \pm 2.4^{c}$ & \\
\hline & Keora + TJ & $31.0 \pm 1.2^{a}$ & \\
\hline & $\mathrm{Tea}+\mathrm{TJ}$ & $38.0 \pm 1.4^{d}$ & \\
\hline & Baen + TJ & $29.0 \pm 2.7^{a}$ & \\
\hline & Papaya + TJ & $26.0 \pm 1.3^{e}$ & \\
\hline & Guava + TJ & $23.0 \pm 2.8^{f}$ & \\
\hline & Garlic + TJ & $37.0 \pm 1.4^{g}$ & \\
\hline & Onion + TJ & $23.0 \pm 1.2^{h}$ & \\
\hline \multirow{9}{*}{ P. aeruginosa } & Fresh TJ & $25.7 \pm 0.3^{a}$ & \multirow{9}{*}{$29.47 \pm 0.87^{a}$} \\
\hline & TJ without extract & $12.5 \pm 2.1^{b}$ & \\
\hline & Keora + TJ & $26.5 \pm 1.3^{a}$ & \\
\hline & Tea + TJ & $39.3 \pm 2.4^{c}$ & \\
\hline & Baen + TJ & $30.4 \pm 1.4^{a}$ & \\
\hline & Papaya + TJ & $25.2 \pm 1.3^{d}$ & \\
\hline & Guava + TJ & $21.7 \pm 1.7^{e}$ & \\
\hline & Garlic + TJ & $33.0 \pm 1.6^{a}$ & \\
\hline & Onion $+\mathrm{TJ}$ & $20.3 \pm 1.3^{f}$ & \\
\hline \multirow{9}{*}{ S. typhi } & Fresh TJ & $26.5 \pm 0.7^{a}$ & \multirow{9}{*}{$29.55 \pm 0.53^{a}$} \\
\hline & TJ without extract & $15.8 \pm 1.8^{b}$ & \\
\hline & Keora +TJ & $27.4 \pm 1.4^{a}$ & \\
\hline & $\mathrm{Tea}+\mathrm{TJ}$ & $36.3 \pm 1.9^{c}$ & \\
\hline & Baen + TJ & $29.7 \pm 1.6^{a}$ & \\
\hline & Papaya + TJ & $23.5 \pm 1.8^{d}$ & \\
\hline & Guava + TJ & $22.4 \pm 1.3^{e}$ & \\
\hline & Garlic + TJ & $34.5 \pm 0.7^{f}$ & \\
\hline & Onion + TJ & $21.2 \pm 1.3^{g}$ & \\
\hline \multirow{9}{*}{ S. pyogenes } & Fresh TJ & $27.8 \pm 0.5^{b}$ & \multirow{9}{*}{$33.43 \pm 0.87^{a}$} \\
\hline & TJ without extract & $12.7 \pm 2.3^{c}$ & \\
\hline & Keora +TJ & $27.6 \pm 1.6^{d}$ & \\
\hline & Tea + TJ & $32.7 \pm 1.8^{a}$ & \\
\hline & Baen + TJ & $28.5 \pm 1.6^{e}$ & \\
\hline & Papaya + TJ & $25.5 \pm 1.6^{f}$ & \\
\hline & Guava + TJ & $24.3 \pm 1.1^{g}$ & \\
\hline & Garlic + TJ & $29.3 \pm 1.9^{h}$ & \\
\hline & Onion + TJ & $24.6 \pm 1.8^{i}$ & \\
\hline
\end{tabular}

Dissimilar small letters in a row indicate significant differences $(\mathrm{p}<0.05)$ of the antimicrobial effect of juice prepared from different extract coated tomatoes, respectively when compared to the standard, while similar small letters in a row indicate the lack of significant differences $(\mathrm{p}<0.05)$ of the antimicrobial effect of the same. 
Thielmann et al., 2017).

\subsection{Cytotoxicity of the extracts}

In the brine shrimp lethality bioassay, the plant extracts showed brine shrimp larvicidal activity in a concentration dependent manner. The leaf extract of keora ( $S$. apetala) showed the lowest $\mathrm{LC}_{50}$ of $132.54 \pm 18.99 \mu \mathrm{g} / \mathrm{mL}$ which was the most toxic among all tested extracts (Fig. 3). The leaf extract of guava ( $P$. guajava) exhibited the next lowest $\mathrm{LC}_{50}$ value of $137.89 \pm 22.21 \mu \mathrm{g} / \mathrm{mL}$. The other extracts could be ranked based on toxicity as garlic ( $A$. sativum) $(234.58 \pm 22.0 \mu \mathrm{g} / \mathrm{mL}$ ) $>$ onion (A. cepa) $(245.84 \pm 12.54 \mu \mathrm{g} / \mathrm{mL})>$ tea $(C$. sinensis $)(324.52 \pm 20.15 \mu \mathrm{g} / \mathrm{mL})>$ baen $(A$. alba $)$ $(453.21 \pm 18.9 \mu \mathrm{g} / \mathrm{mL})$. It has been reported that $\mathrm{LC}_{50}$ values in the range of $100-500 \mu \mathrm{g} / \mathrm{mL}$ are considered moderately toxic (Salawu et al., 2017). Therefore, $\mathrm{LC}_{50}$ values obtained in this study indicate moderate toxicity for the plant extracts. In addition, it was suggested that, if crude extracts possessed $\mathrm{LC}_{50}$ values less than $250 \mu \mathrm{g} / \mathrm{mL}$ they could be considered significantly active and have the potential for further investigation (Nair, Anju \& Hatha, 2017). Therefore, the preliminary cytotoxic activity exhibited by the extracts was promising and this clearly indicated the presence of potent bioactive compounds.

\subsection{Nutrient analysis}

Analytical results of moisture, changes in weight, $\mathrm{pH}$, total carbohydrate and protein content before and after treatment of the tomato samples are shown in Table 2. Moisture content influences the physical, chemical and microbiological aspects of food, and the keeping qualities of freshness and firmness during the storage of the food for a long period of time. The moisture content of the fresh tomato was $89.93 \%$. The leaf extract of keora $(S$. apetala) treated tomato retained the highest moisture content of $80.61 \%$ whereas the lowest value was found to be $67.47 \%$ for onion (A. cepa) extract treated samples. The moisture content of plant extract treated samples was found to be significantly different from each other. The highest percentage of change in weight observed was in the onion $(A$. серa) extract treated tomato $(20.28 \%)$, followed by the garlic (A. sativum) treated samples $(20.02 \%)$, while the lowest value was obtained in the leaf extract of keora $(S$. apetala) treated samples. However, the changes in weight were significantly different when plant extract treated samples were compared to tomatoes stored without any plant extract application (control) at day 12. The control displayed a rapid decline in weight $(\%)$ and the highest changes in weight percentage at day 12 as compared to all other treatments at that stage. This could be attributable to uncontrolled ripening of tomatoes, as ripening in tomatoes could be regarded as climacteric with a sudden increase in ethylene production and respiration rate. This higher respiration rate also resulted in higher transpiration of water from the fruit surface which led to an increase in percentage of changes in weight during storage (Sabir, Shah \& Afzal, 2004; Zagory \& Kader, 1988). Thus, physiological changes in weight of tomatoes were influenced by different extract applications. Moreover, as cited by Proulx, Cecilia, Nunes, Emond and Brecht (2005), high storage temperature led to accelerated water loss and subsequent shrivelling and softening of the fruit. Furthermore, lower changes in weight of tomatoes could be due to a slow rate of ripening and prevention of excessive moisture loss on application of different extracts to tomatoes (Haile, 2018; Seyoum \& Woldetsadik, 2004). Zhang and Quantick (1997) mentioned similar results for litchi coated with an edible coating of chitosan.

The $\mathrm{pH}$ value is a measure of acidity or alkalinity of water-soluble substances. The $\mathrm{pH}$ value is one of the most important factors which influences food properties. The $\mathrm{pH}$ of tomatoes is determined primarily by the acid content of the fruit, termed titratable acidity (TA). The acidity of the fruit also contributes to the flavor of tomato products. The $\mathrm{pH}$ value of the fresh tomato was 4.08 and the $\mathrm{pH}$ value increased after treatment of the sample. The lowest $\mathrm{pH}$ value of 4.16 was found in the tomato coated with the leaf extract of keora ( $S$. apetala) whereas the highest value of 6.56 was observed in the tomato coated with the onion extract. However, the tomato without any extract coating showed the highest change in $\mathrm{pH}$ on comparing samples at day 0 and after 12 days 
SI104 | Islam et al.

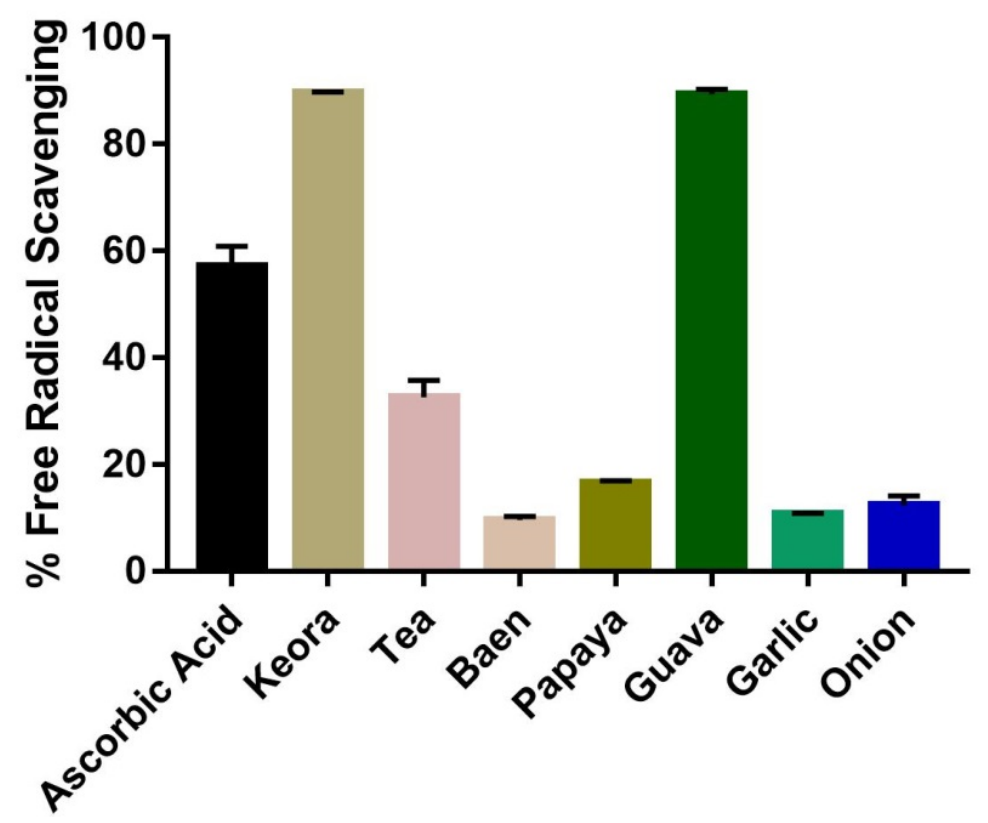

Extracts

Figure 1: Percentage free radical scavenging of different plant extracts $(\mathrm{n}=3)$.

of storage. The rise in $\mathrm{pH}$ could be related to a decline in TA due to a loss of citric acid. Citric acid is the most abundant organic acid in tomatoes. The decrease in TA could be associated with increased fruit ripening and subsequent decay which would lead to loss of citric acid from tomatoes. It has been reported that during tomato ripening, as in other fruits, a decline in acid levels is accompanied by an increase in sugars. At least a portion of this change may be due to the metabolic conversion of acids into sugars by gluconeogenesis. In addition, the loss of organic acids from tomatoes could occur through respiration during storage (Anthon, LeStrange \& Barrett, 2011). It has been suggested that 4.4 is the maximum desirable $\mathrm{pH}$ for safety and the optimum target $\mathrm{pH}$ should be 4.25 (Monti, 1979). The present finding is supported by the result observed on apple samples by Coseteng and Lee (1987).

Carbohydrates are a large group of organic com- pounds occurring in foods and living tissues, and include sugars, starches and cellulose. The total carbohydrate and protein contents of the control sample were 2.42 and $0.82 \%$, respectively. The highest total carbohydrate content was estimated as $2.04 \%$ in tomatoes coated with the leaf extract of keora (S. apetala) while the lowest value determined was $0.87 \%$ for tomatoes coated with onion (A. cepa) extract. The highest protein content was $0.73 \%$ for tomatoes coated with the leaf extract of keora ( $S$. apetala) whilst tomatoes coated with extracts of onion (A. cepa) and garlic (A. sativum) showed the lowest value of $0.49 \%$ after storage for 12 days. Nutrient results for carbohydrates and protein were supported by the work of Jiang, Li and Jiang (2005) who investigated the effects of an edible chitosan coating on the litchi fruits at ambient temperature and Martinez-Romero et al. (2006) who studied the influence of aloe-vera on the storage of sweet cherries. 


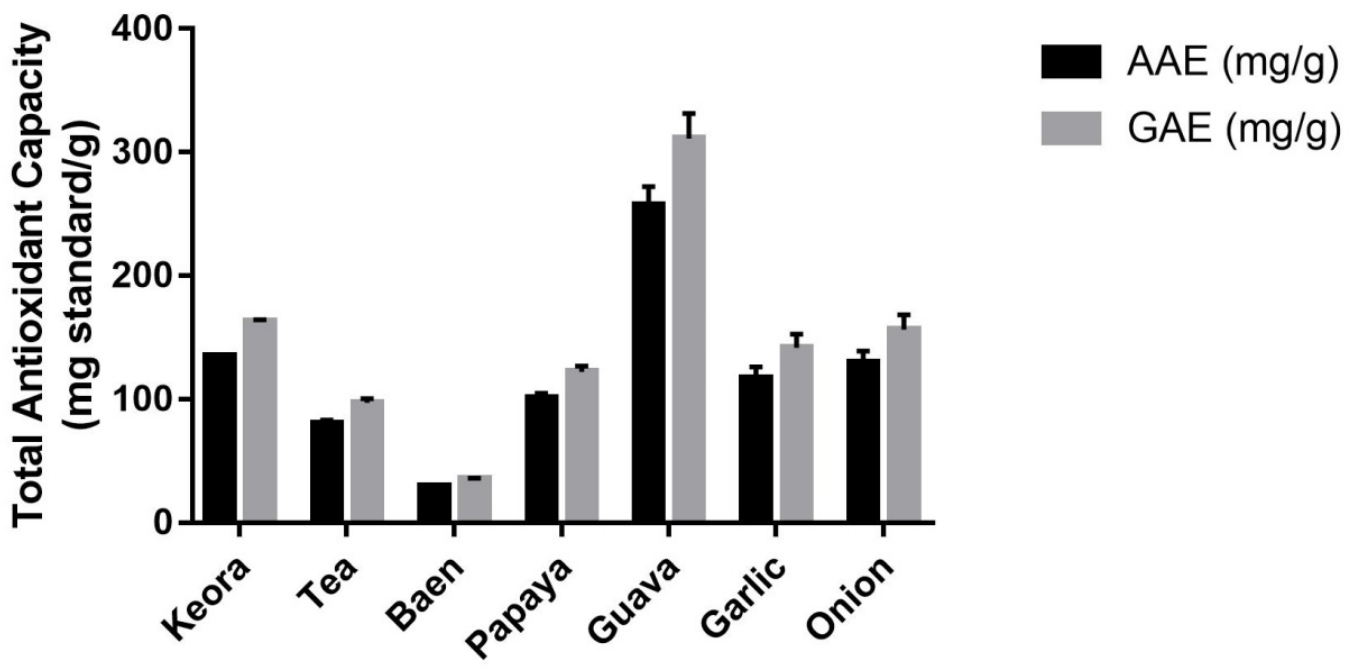

\section{Extracts}

Figure 2: Total antioxidant capacity of different plant extracts, both ascorbic acid equivalent (AAE) and gallic acid equivalent (GAE), respectively in $\mathrm{mg} / \mathrm{g}$.

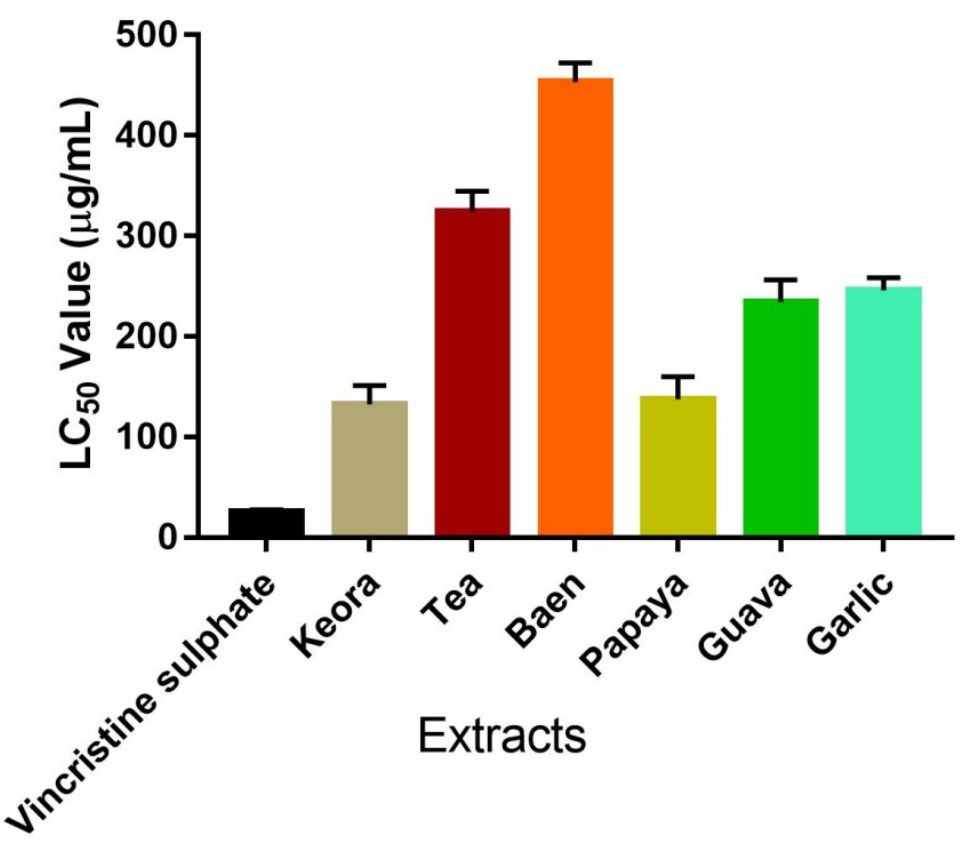

Figure 3: $\mathrm{LC}_{50}$ values of different plant extracts and control $(\mathrm{n}=3)$. 
SI106 | Islam et al.

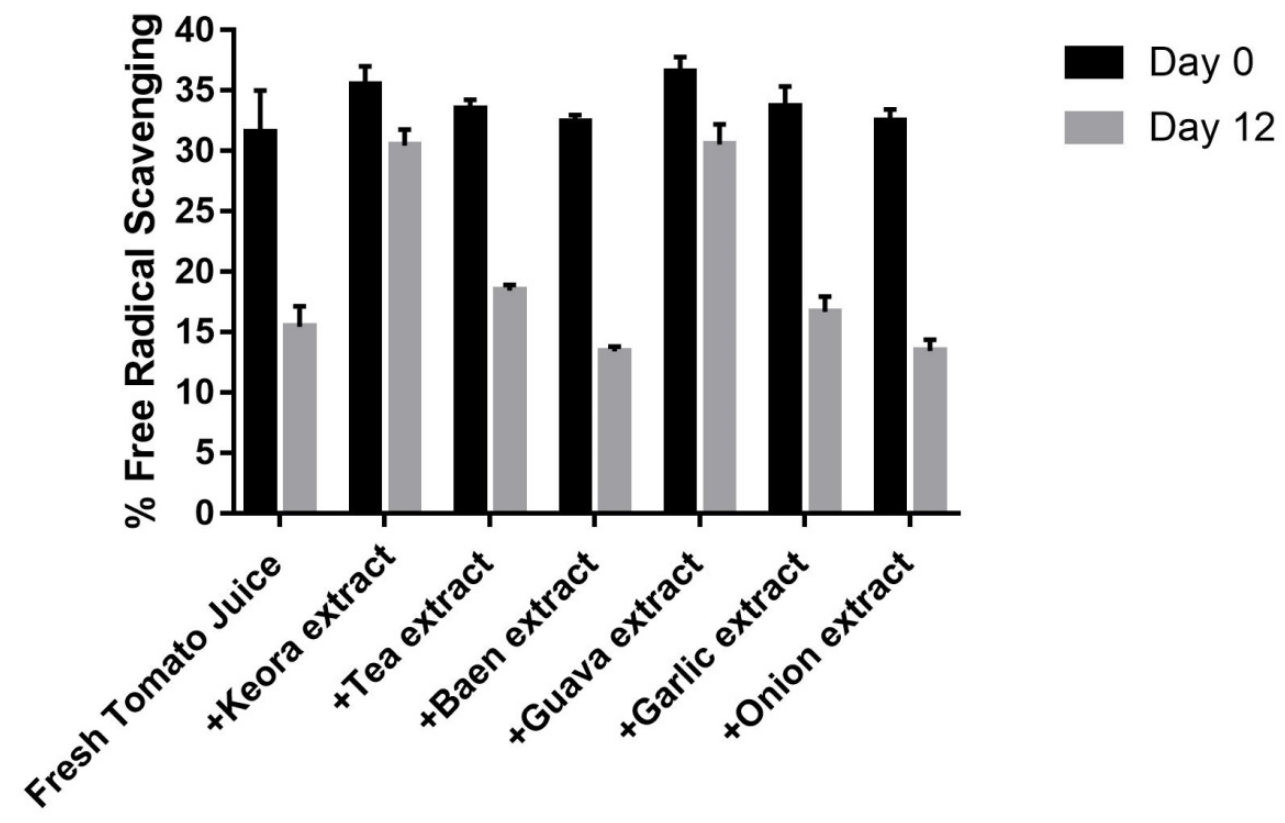

Extracts

Figure 4: Free radical scavenging assay of different juices prepared from extract coated tomatoes at day 0 and 12 , fresh tomato juice at day 0 , tomato juice without any extract at day 12 .

\subsection{Antimicrobial activities of preserved tomatoes}

Tomato juice prepared from different tomatoes which had been coated with an extract showed varying levels of antibacterial properties after storage for 12 days (Table 3 ). Of these, juice prepared from tea extract treated tomatoes showed the highest level of activity against the tested bacteria. It should be noted that fresh tomato juice also showed strong antibacterial properties when compared to values obtained from the control which is in agreement with previous findings (Maz'uma, Dadah \& Uba, 2018). Juices from extract coated tomatoes were able to produce a zone of inhibition close to erythromycin. For E. coli, P. aeruginosa, S. typhi and S. pyogenes, juice from extract of garlic (A. sativum) and leaf extract of tea ( $C$. sinensis) coated tomatoes produced a larger zone of inhibition than control values which were statistically significant $(\mathrm{p}<0.005)$. The results indicate that a synergistic effect of both extracts and tomato juice could contribute towards appearance of larger zones of inhibition than seen for both free fresh tomato juice and erythromycin, respectively. In addition, the leaf extract of baen ( $A$. alba), keora ( $S$. apetala) and garlic (A. sativum) showed strong antibacterial activities against $P$. aeruginosa, $S$. typhi and $S$. pyogenes, respectively. In all cases, juice prepared from both onion ( $A$. cepa) and the leaf extract of guava ( $P$. guajava) coated tomatoes showed poorest antibacterial properties, and from papaya (C. papaya) coated tomatoes showed moderate antibacterial properties. 


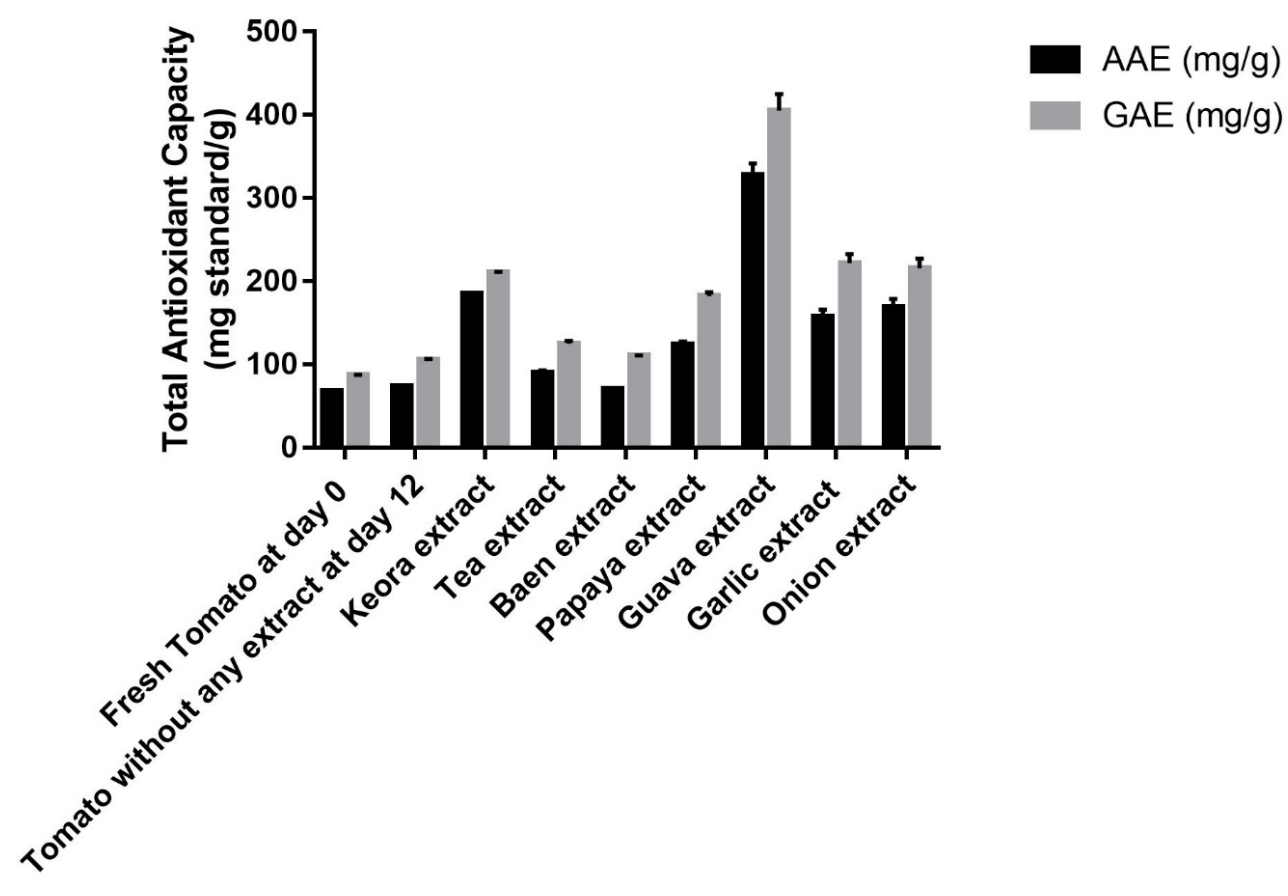

Extracts

Figure 5: Total antioxidant capacity of different juices prepared from extract coated tomatoes at day 0 and 12, fresh tomato juice at day 0, tomato juice without any extract at day 12; expressed in both Ascorbic Acid Equivalent (AAE, mg/g) and Gallic Acid Equivalent (GAE, mg/g).

\subsection{Antioxidant properties of preserved tomatoes}

The phenolic content of tomato fruits has been correlated with their antioxidant capacity. Similar to free radical scavenging assay findings, DPPH free radical scavenging assay findings for juices from different extract coated tomatoes showed varying levels of activity (Fig. 4). Juice from leaf extract of keora (S. apetala) and extract of guava ( $P$. guajava) coated tomatoes showed the highest free radical scavenging activity. Fresh tomato juice (day 0) also showed a substantial level of activity as reported by de Abreu, Piccolo Barcelos, de Barros Vilas Boas and da Silva (2014) and Balaswamy (2015), however, the activity declined after storage for 12 days. Extract treated tomatoes were able to retain their activity as evident from Figure 1. As the amount of extract applied was $0.5 \%$, the free radical scavenging did not increase substantially when compared with the results obtained for the extracts alone. However, the total antioxidant capacity of juice prepared from tomatoes without any extract increased slightly from day 0 to day 12 , although this was not statistically significant (Fig. 5). The increase in antioxidant capacity could be related to the lower moisture content at day 12 . The leaf extract of guava $(P$. guajava) showed the highest antioxidant capacity for both AAE and GAE values $(\mathrm{mg} / \mathrm{g})$ which was highly significant $(\mathrm{p}<0.0001)$. Statistically significant values were also shown in terms of both AAE and GAE values $(\mathrm{mg} / \mathrm{g})$ for the extracts of onion $(A$. cepa) and garlic (A. sativum) and the leaf extract of keora $(S$. apetala). Storage of tomatoes coated with different extracts favors the liberation of phenolic compounds and lycopene, the 
main antioxidant compound present in tomatoes from the cellular matrix. Thus, phenolic compounds and lycopene were more bioavailable in tomatoes subjected to storage and dehydration in the process of preservation (de Abreu et al., 2014; Toor, Savage \& Lister, 2009). It is considered that these phenolic compounds improve the nutritional value and functional properties of tomatoes.

\section{Conclusion}

The studied plant extracts showed different levels of antimicrobial, antioxidant and cytotoxic activity due to differences in phenolic compounds, and the amount and concentration of extracts applied to tomatoes. Although the study is preliminary in nature, it has provided valuable insights about the use of plant extracts in food preservation. The current study indicates that leaf extracts of tea $(C$. sinensis), keora $(S$. apetala) and guava $(P$. guajava) and the extract of garlic $(A$. sativum) can be used for potential applications in preventing the adverse effects of food spoilage.

Chemical and synthetic preservatives are still used for preventing food spoilage in the food industry. The adverse effects of these chemical preservatives on human health necessitate the search for potentially effective, healthier, safer and natural food preservatives based on plant sources. It is a common belief that biologically active pure compounds are more effective than crude extracts. However, to get the overall view of plant extracts for prevention of food deterioration and extension of shelf-life, it is essential to consider crude extracts. As food spoilage is usually associated with the growth of different pathogenic bacterial strains and oxidation of food components, further study is required to investigate the application of these extracts in food preservation.

\section{References}

Amarowicz, R., Pegg, R. B., RahimiMoghaddam, P., Barl, B. \& Weil, J. A. (2004). Free-radical scavenging capacity and antioxidant activity of selected plant species from the canadian prair- ies. Food Chemistry, 84(4), 551-562. doi:10.1016/S0308-8146(03)00278-4

Anthon, G. E., LeStrange, M. \& Barrett, D. M. (2011). Changes in ph, acids, sugars and other quality parameters during extended vine holding of ripe processing tomatoes. Journal of the Science of Food and Agriculture, 91 (7), 1175-1181. doi:10.1002/jsfa. 4312

AOAC. (2005). Offcial Methods of Analysis. 14th ed. Washington, D.C.: Association of Offcial Analytical Chemists.

Balaswamy, K. (2015). Antioxidant activity of tomato (lycopersicon esculentum l.) of low soluble solids and development of a shelf stable spread. Int $J$ Food Sci Nutr Diet, 4(4), 202-207.

Bauer, A. W., Kirby, W. M. M., Sherris, J. C. \& Turck, M. (1966). Antibiotic susceptibility testing by a standardized single disk method. American Journal of Clinical Pathology, 45(4), 493-\&.

Brand-williams, W., Cuvelier, M. \& Berset, C. (1995). Use of a free-radical method to evaluate antioxidant activity. LWT-Food Science and Technology, 28(1), 25-30.

Brishti, F. H., Misir, J. \& Sarker, A. (2013). Effect of biopreservatives on storage life of papaya (carica papaya 1.) International Journal of Food Studies, 2(1).

Burt, S. (2004). Essential oils: Their antibacterial properties and potential applications in foods - a review. International journal of food microbiology, 94(3), 223-253.

Calo, J. R., Crandall, P. G., O'Bryan, C. A. \& Ricke, S. C. (2015). Essential oils as antimicrobials in food systems-a review. Food Control, 54, 111-119. doi:10.1016/j. foodcont.2014.12.040

Carovic-Stanko, K., Orlic, S., Politeo, O., Strikic, F., Kolak, I., Milos, M. \& Satovic, Z. (2010). Composition and antibacterial activities of essential oils of seven ocimum taxa. Food Chemistry, 119(1), 196-201. doi:10.1016/j.foodchem.2009.06.010

Cleveland, J., Montville, T. J., Nes, I. F. \& Chikindas, M. L. (2001). Bacteriocins: Safe, natural antimicrobials for food preservation. International journal of food microbiology, 71 (1), 1-20. 
Coseteng, M. Y. \& Lee, C. Y. (1987). Changes in apple polyphenoloxidase and polyphenol concentrations in relation to degree of browning. Journal of Food Science, 52(4), 985-989. doi:10.1111/j.1365-2621.1987. tb14257.x

de Abreu, W. C., Piccolo Barcelos, M. d. F., de Barros Vilas Boas, E. V. \& da Silva, E. P. (2014). Total antioxidant activity of dried tomatoes marketed in Brazil. International Journal of Food Properties, 17(3), 639-649. doi:10.1080/10942912.2012.654703

Djeridane, A., Yousfi, M., Nadjemi, B., Boutassouna, D., Stocker, P. \& Vidal, N. (2006). Antioxidant activity of some algerian medicinal plants extracts containing phenolic compounds. Food Chemistry, 97(4), 654660. doi:10.1016/j.foodchem.2005.04.028

Donsi, F. \& Ferrari, G. (2016). Essential oil nanoemulsions as antimicrobial agents in food. Journal of Biotechnology, 233, 106120. doi:10.1016/j.jbiotec.2016.07.005

Dorman, H. J. D. \& Deans, S. G. (2000). Antimicrobial agents from plants: Antibacterial activity of plant volatile oils. Journal of Applied Microbiology, 88(2), 308-316. doi:10.1046/j.1365-2672.2000.00969.x

Dwivedy, A. K., Kumar, M., Upadhyay, N., Prakash, B. \& Dubey, N. K. (2016). Plant essential oils against food borne fungi and mycotoxins. Current Opinion in Food Science, 11, 16-21. doi:10.1016/j.cofs.2016.08. 010

Friedman, M., Henika, P. R., Levin, C. E. \& Mandrell, R. E. (2004). Antibacterial activities of plant essential oils and their components against escherichia coli o157 : H7 and salmonella enterica in apple juice. Journal of Agricultural and Food Chemistry, 52(19), 6042-6048. 224th National Meeting of the American-ChemicalSociety, BOSTON, MA, AUG 17-22, 2002. doi:10.1021/jf0495340

Gill, A. O. \& Holley, R. A. (2006). Disruption of escherichia coli, listeria monocytogenes and lactobacillus sakei cellular membranes by plant oil aromatics. International Journal of Food Microbiology, 108(1), 1-9. doi:10. 1016/j.ijfoodmicro.2005.10.009
Gupta, M., Mazumdar, U. K., Sivahkumar, T., Vamis, M. L. M., Karki, S., Sambathkumar, R. \& Manikandan, L. (2003). Antioxidant and anti-inflammatory activities of acalypha fruticosa. Nigerian Journal of Natural Products and Medicine, 7(1), 2529.

Hac-Wydro, K., Flasinski, M. \& Romanczuk, K. (2017). Essential oils as food ecopreservatives: Model system studies on the effect of temperature on limonene antibacterial activity. Food Chemistry, 235, 127135. doi:10.1016/j.foodchem.2017.05.051

Haile, A. (2018). Shelf life and quality of tomato (lycopersicon esculentum mill.) fruits as affected by different packaging materials. African Journal of Food Science, 2(2), 21-27.

Hammer, K. A., Carson, C. F. \& Riley, T. V. (1999). Antimicrobial activity of essential oils and other plant extracts. Journal of Applied Microbiology, 86(6), 985-990. doi:10.1046/j.1365-2672.1999.00780.x

Hintz, T., Matthews, K. K. \& Di, R. (2015). The use of plant antimicrobial compounds for food preservation. Biomed Research International. doi:10.1155/2015/246264

Islam, T., Afrin, N., Parvin, S., Dana, N. H., Rahman, K. S., Zzaman, W. \& Islam, M. N. (2018). The impact of chitosan and guava leaf extract as preservative to extend the shelf-life of fruits. International Food Research Journal, 25(5), 2056-2062.

Jiang, Y., Li, J. \& Jiang, W. (2005). Effects of chitosan coating on shelf life of cold-stored litchi fruit at ambient temperature. $L W T$ Food Science and Technology, 38(7), 757761.

Khan, I., Ullah, S. \& Oh, D.-H. (2016). Chitosan grafted monomethyl fumaric acid as a potential food preservative. Carbohydrate Polymers, 152, 87-96. doi:10.1016/j . carbpol.2016.06.073

King, T., Cole, M., Farber, J. M., Eisenbrand, G., Zabaras, D., Fox, E. M. \& Hill, J. P. (2017). Food safety for food security: Relationship between global megatrends and developments in food safety. Trends in Food Science \& Technology, 68, 160-175. doi:10. 1016/j.tifs.2017.08.014 
Kumar, D. \& Kalita, P. (2017). Reducing postharvest losses during storage of grain crops to strengthen food security in developing countries. Foods, 6(1). doi:10.3390/ foods 6010008

Lee, S. E., Hwang, H. J., Ha, J. S., Jeong, H. S. \& Kim, J. H. (2003). Screening of medicinal plant extracts for antioxidant activity. Life Sciences, 73(2), 167-179. doi:10. 1016/S0024-3205(03)00259-5

Lowry, O. H., Rosebrough, N. J., Farr, A. L. \& Randall, R. J. (1951). Protein measurement with the folin phenol reagent. Journal of Biological Chemistry, 193(1), 265-275.

Ma, M., Wen, X., Xie, Y., Guo, Z., Zhao, R., Yu, P., .. Z Zeng, Z. (2018). Antifungal activity and mechanism of monocaprin against food spoilage fungi. Food Control, 84, 561-568. doi:10.1016/j.foodcont.2017.07.022

Martinez-Romero, D., Alburquerque, N., Valverde, J. M., Guillen, F., Castillo, S., Valero, D. \& Serrano, M. (2006). Postharvest sweet cherry quality and safety maintenance by aloe vera treatment: A new edible coating. Postharvest Biology and Technology, 39(1), 93-100. doi:10 . 1016 / j . postharvbio.2005.09.006

Maz'uma, A., Dadah, A. J. \& Uba, A. (2018). Antibacterial activity of citrus sinensis and solanum lycopersicum on wound isolated from hospitals in kaduna metropolis kaduna nigeria. International Journal of Biomedical Materials Research, 6(2), 40.

Monti, L. M. (1979). The breeding of tomatoes for peeling. In Symposium on production of tomatoes for processing 100 (pp. 341-354).

Mwangi, G. G., Wagacha, J. M., Nguta, J. M. \& Mbaria, J. M. (2015). Brine shrimp cytotoxicity and antimalarial activity of plants traditionally used in treatment of malaria in msambweni district. Pharmaceutical biology, 53(4), 588-593.

Nair, I. M., Anju, V. \& Hatha, A. A. M. (2017). Antibacterial activity of medicinal plants used in ayurvedic medicine towards food and water borne pathogens. Journal of Environmental Biology, 38(2), 223-229.

Nakanishi, Y., Irie, K. \& Murata, M. (2018). Factors affecting the suitability of boiled pasta with tomato sauce for eating. $L W T$ -
Food Science and Technology, 24(1), 159167. doi:10.3136/fstr.24.159

Negi, P. S. (2012). Plant extracts for the control of bacterial growth: Efficacy, stability and safety issues for food application. International Journal of Food Microbiology, 156(1), 7-17. doi:10.1016/j . ijfoodmicro . 2012.03 .006

Okoye, C. O. B. \& Ugwu, J. N. (2008). Evaluation of three methods of sugar analyses for determination of low-level sugar in fruits. Plant Products Research Journal, 12(1), 19-22.

Prieto, P., Pineda, M. \& Aguilar, M. (1999). Spectrophotometric quantitation of antioxidant capacity through the formation of a phosphomolybdenum complex: Specific application to the determination of vitamin e. Analytical Biochemistry, 269(2), 337-341. doi:10.1006/abio.1999.4019

Proulx, E., Cecilia, M., Nunes, N., Emond, J. P. \& Brecht, J. K. (2005). Quality attributes limiting papaya postharvest life at chilling and non-chilling temperatures. In Proceedings of the florida state horticultural society (Vol. 118, pp. 389-395).

Rahman, M. M., Islam, M. B., Biswas, M. \& Alam, A. K. (2015). In vitro antioxidant and free radical scavenging activity of different parts of tabebuia pallida growing in bangladesh. BMC research notes, 8(1), 621.

Reto, M., Figueira, M. E., Filipe, H. M. \& Almeida, C. M. M. (2007). Chemical composition of green tea (camellia sinensis) infusions commercialized in Portugal. Plant Foods for Human Nutrition, 62(4), 139144. doi:10.1007/s11130-007-0054-8

Sabir, M. S., Shah, S. Z. A. \& Afzal, A. (2004). Effect of chemical treatment, wax coating, oil dipping and different wrapping materials on physio-chemical characteristics and storage behavior of apple (Malus domestica Borkh). Pakistan Journal of Nutrition, 3(2), 122-127.

Salawu, K. M., Ajaiyeoba, E. O., Ogbole, O. O., Adeniji, J. A., Faleye, T. C. \& Agunu, A. (2017). Antioxidant, brine shrimp lethality, and antiproliferative properties of gel and leaf extracts of aloe schweinfurthii and aloe 
vera. Journal of Herbs, Spices \& Medicinal Plants, 23(4), 263-271.

Sarkar, D. \& Shetty, K. (2014). Metabolic stimulation of plant phenolics for food preservation and health. In M. P. Doyle \& T. R. Klaenhammer (Eds.), Annual review of food science and technology, vol 5 (Vol. 5, pp. 395-413). Annual Review of Food Science and Technology. doi:10.1146/ annurev-food-030713-092418

Seyoum, T. \& Woldetsadik, K. (2004). Forced ventilation evaporative cooling: A case study on banana, papaya, orange, mandarin, and lemon. Trop Agric, 81, 1-6.

Shiekh, R. A., Malik, M. A., Al-Thabaiti, S. A. \& Shiekh, M. A. (2013). Chitosan as a novel edible coating for fresh fruits. LWT- Food Science and Technology, 19(2), 139-155. doi:10.3136/fstr.19.139

Skrovankova, S., Sumczynski, D., Mlcek, J., Jurikova, T. \& Sochor, J. (2015). Bioactive compounds and antioxidant activity in different types of berries. International Journal of Molecular Sciences, 16(10), 24673-24706. doi:10.3390/ijms161024673

Sumaiya, K., Jahurul, M. H. A. \& Zzaman, W. (2018). Evaluation of biochemical and bioactive properties of native and imported pomegranate (punica granatum l.) cultivars found in bangladesh. International Food Research Journal, 25(2), 737-746.

Thielmann, J., Kohnen, S. \& Hauser, C. (2017). Antimicrobial activity of olea europaea linne extracts and their applicability as natural food preservative agents. International Journal of Food Microbiology, 251, 48-66. doi:10.1016/j.ijfoodmicro.2017.03. 019

Thorat, I. D., Jagtap, D. D., Mohapatra, D., Joshi, D. C., Sutar, R. F. \& Kapdi, S. S. (2013). Antioxidants, their properties, uses in food products and their legal implications. International Journal of Food Studies, 2(1).

Tiwari, B. K., Valdramidis, V. P., O'Donnell, C. P., Muthukumarappan, K., Bourke, P. \& Cullen, P. J. (2009). Application of natural antimicrobials for food preservation. Journal of Agricultural and Food Chem- istry, 57(14), 5987-6000. doi:10 . 1021/ jf900668n

Toor, R. K., Savage, G. P. \& Lister, C. E. (2009). Release of antioxidant components from tomatoes determined by an in vitro digestion method. International Journal of Food Sciences and Nutrition, 60(2), 119129. doi:10.1080/09637480701614121

Zagory, D. \& Kader, A. A. (1988). Modified atmosphere packaging of fresh produce. Food Technol, 42(9), 70-77.

Zhang, D. L. \& Quantick, P. C. (1997). Effects of chitosan coating on enzymatic browning and decay during postharvest storage of litchi (litchi chinensis sonn.) fruit. Postharvest Biology and Technology, 12(2), 195202. doi:10.1016/S0925-5214(97)00057-4 